\title{
HUBUNGAN PENGETAHUAN, SIKAP DAN PRAKTIK PENGUNJUNG TERHADAP PENCEGAHAN DEMAM BERDARAH DENGUE DI PUSAT KESEHATAN MASYARAKAT TELUK BAYUR KABUPATEN BERAU TAHUN 2018
}

\author{
Kartina Wulandari ${ }^{1}$, Aditya Ananda Ramadhan ${ }^{2}$, \\ kartinawulandari89@gmail.com ${ }^{1}$, adityapro2013@gmail.com ${ }^{2}$ \\ Universitas Widyagama Mahakam Samarinda
}

\begin{abstract}
ABSTRAK
Demam Berdarah Dengue (DBD) adalah penyakit yang disebabkan oleh virus dengue. DBD ditularkan melalui gigitan nyamuk dari genus Aedes, terutama Aedes aegypti. Menurut data Badan Kesehatan Dunia, Asia Pasifik menanggung 75 persen dari beban dengue di dunia antara tahun 2004 dan 2010, sementara Indonesia dilaporkan sebagai negara ke-2 dengan kasus DBD terbesar diantara 30 negara wilayah endemis. Penelitian ini bertujuan untuk mengetahui hubungan antara pengetahuan, sikap dan Praktik Pengunjung terhadap pencegahan Demam Berdarah Dengue Di Puskesmas Teluk Bayur Kabupaten Berau Tahun 2018. Jenis penelitian ini adalah Cross Sectional dengan jumlah sampel sebanyak 100 responden. Analisis data yang digunakan adalah uji Chi square. Hasil penelitian diperoleh bahwa Ada Hubungan pengetahuan pengunjung terhadap kejadian DBD, Ada Hubungan sikap pengunjung terhadap kejadian DBD, Tidak Ada Hubungan pratik pengunjung terhadap kejadian DBD Di Puskesmas Teluk Bayur Kabupaten Berau. Disarankan bagi petugas Puskesmas untuk melakukan penyuluhan $3 \mathrm{M}$ Plus, bagi masyarakat melakukan kegiatan $3 \mathrm{M}$ Plus, di bentuk tenaga jumatik, menggunakan abate dan bagi penelitian agar di lakukan penelitian DBD dengan variabel dan tempat berbeda.

Kata Kunci : Pengetahuan, Sikap, Praktik, DBD
\end{abstract}

\begin{abstract}
Dengue Hemorrhagic Fever (DHF) is a disease caused by the dengue virus belonging to the Arthropod-Borne Virus, the genus Flavivirus, and the family Flaviviridae. DHF is transmitted through mosquito bites from the genus Aedes, especially Aedes aegypti. According to World Health Organization data, the Asia Pacific bears 75 percent of the world's dengue burden between 2004 and 2010, while Indonesia is reported as the second country with the largest DHF cases among 30 endemic regional countries. This study aims to determine the relationship between knowledge, attitudes and visitor practices towards the prevention of dengue hemorrhagic fever at Teluk Bayur Health Center, Berau Regency in 2018. This type of research is Cross Sectional with a total sample of 100 respondents. The data analysis used is the Chi square test. The results showed that there was a relationship between visitors' knowledge of the incidence of DHF, there was a relationship between visitor attitudes towards the incidence of dengue, there was no relationship between physical visitors to the incidence of dengue at Teluk Bayur Health Center, Berau District. It is recommended for Puskesmas officers to conduct $3 \mathrm{M}$ Plus counseling, for the community to carry
\end{abstract}


out 3 M Plus activities, in the form of Friday medical staff, using abate and for research to be carried out in DHF research with different variables and places.

Keywords: Knowledge, Attitudes, Practices, DHF

\section{PENDAHULUAN}

\section{A. Latar Belakang}

Demam Berdarah Dengue (DBD) adalah penyakit yang disebabkan oleh virus dengue yang tergolong ArthropodBorne Virus, genus Flavivirus, dan family Flaviviridae. DBD ditularkan melalui gigitan nyamuk dari genus Aedes, terutama Aedes aegypti (infodatin, 2016). Penyakit DBD dapat muncul sepanjang tahun dan dapat menyerang seluruh kelompok umur. Munculnya penyakit ini berkaitan dengan kondisi lingkungan dan perilaku masyarakat (Kemenkes RI, 2016).

Menurut data Badan Kesehatan Dunia (WHO), Asia Pasifik menanggung 75 persen dari beban dengue di dunia antara tahun 2004 dan 2010, sementara Indonesia dilaporkan sebagai negara ke-2 dengan kasus DBD terbesar diantara 30 negara wilayah endemis (CNN INDONESIA,2016).

Jumlah kasus DBD fluktuatif setiap tahunnya. Data dari Direktorat Pencegahan dan Pengendalian Penyakit Tular Vektor dan Zoonotik, Kemenkes RI, pada 2014 jumlah penderita mencapai 100,347, 907 orang diantaranya meninggal. Pada 2015, sebanyak 129,650 penderita dan 1,071 kematian. Sedangkan di 2016sebanyak 202,314 penderita dan 1,593 kematian (Kemenkes RI,2017).

Menurut profil kesehatan Kalimantan Timur tahun 2016 Jumlah kasus DBD mengalami peningkatan setiap tahunnya, dimana pada tahun 2013 sebesar 3.694 kasus, meningkat pada tahun 2014 menjadi 6.709 kasus dan kembali meningkat pada tahun 2015 menjadi 7.305 kasus dan kembali meningkat pada tahun 2016 menjadi 10.878 kasus.

Berdasarkan data Dinas

Kesehatan Kabupaten Berau terjadi kenaikan maupun penurunan kasus DBD dengan Rincian tahun 2014 ada sekira 318 kasus, 896 kasus di tahun 2015, 437 kasus pada tahun 2016, dan 288 kasus pada tahun 2017.

Salah satu Pusat kesehatan masyarakat yang mengalami penigkatan kasus kejadian DBD ada di Kabuten Berau adalah Pusat kesehatan masyarakat Teluk Bayur yang berada di kelurahan Teluk bayur. Berdasarkan laporan dari Pusat kesehatan masyarakat Teluk Bayur pada 2015 terjadi 17 kasus, pada tahun 2016 menjadi 20 kasus dan ini mengalami peningkatan pada tahun 2017 menjadi 25 kasus.

Hasil survey pendahuluan yang dilakukan di Pusat kesehatan masyarakat Teluk Bayur pada bulan Februari tahun 2018 terhadap 10 pengunjung didapatkan hasil sebanyak 6 pengunjung mengatakan tidak mengetahui terhadap upaya pencegahan DBD dan 4 pengunjung mengatakan mengetahui terhadap upaya pencegahan DBD.

Berdasarkan latar belakang, peneliti tertarik untuk meneliti terhadap Hubungan Pengetahuan, Sikap Dan Praktik Pengunjung Terhadap Pencegahan Demam Berdarah Dengue Di Pusat Kesehatan Masyarakat Teluk Bayur Kabupaten Berau. 


\section{B. Rumusan Masalah}

Berdasarkan latar belakang masalah di atas maka rumusan masalah dalam penelitian ini adalah bagaimana Hubungan pengetahuan, sikap dan Praktik pengunjung terhadap pencegahan demam berdarah dengue di Pusat kesehatan masyarakat Teluk Bayur.

\section{Metode Penelitian}

Penelitian ini termasuk penelitian observasional analitik dengan pendekatan Cross Sectional yaitu jenis penelitian yang menekankan pada waktu pengukuran atau observasi data dalam satu kali pada satu waktu yang dilakukan pada variable terikat dan variabel bebas. Pendekatan ini digunakan untuk melihat hubungan antara variabel satu dengan variabel lainnya. Variabel yang di ukur pada penelitian ini adalah pengetahuan, sikap, dan praktik pengunjung terhadap pencegahan DBD.

Dalam penelitian ini sampel yang di ambil adalah 100 pengunjung Puskemas Teluk Bayur dari Pengunjung Puskesmas Teluk Bayur yang berumur dari 17 hingga 45 tahun pada bulan Agustus 2018 dalam satu bulan terakhir yang berjumlah 190 .

Teknik pengumpulan di peroleh dengan cara mengajukan kuisioer kepada responden yang memenuhi kreteria. Kuesioner yang dipakai dalam penelitian ini sebelumnya telah dilakukan pengujian vasliditas kuesioner terhadap populasi lain. Kuesioner juga ada yang berupa pertanyaan penyaring untuk menyaring sampel agar sesuai dengan kriteria restriksi. lembar kuesioner digunakan untuk mengetahui tingkat Pendidikan, tingkat ekonomi, riwayat keluarga menderita DBD, usia, pengetahuan, sikap, dan praktik.

Data dianalisis dengan SPSS (Statistical Product and Service
Solutions) versi 23 Setelah data terkumpul sesuai kriteria yang ditetapkan, kemudian data diolah dan disusun dalam tabel induk. Pengolahan data dengan menggunakan komputer. Analisis data dengan menggunakan Analisis Univariat, pada tahap ini dilakukan untuk memberikan gambaran karakteristik responden dengan distribusi frekuensi. Analisis Bivariat digunakan untuk mengetahui hubungan atau korelasi antara variabel bebas dan variabel terikat dengan Uji Chi square $\left(\mathrm{X}^{2}\right)$ dengan kontingensi tabel $2 \times 2$.

\begin{tabular}{|c|c|c|c|}
\hline \multirow{2}{*}{$\begin{array}{c}\text { Faktor } \\
\text { Resiko }\end{array}$} & \multicolumn{2}{|c|}{ Efek } & \multirow{2}{*}{ Jumlah } \\
\cline { 2 - 3 } & + & - & \\
\hline+ & A & b & a+b \\
\hline- & C & d & c +d \\
\hline Jumlah & a+c & b+d & a+b+c+d \\
\hline
\end{tabular}

Keterangan :

$\mathrm{a}=$ subyek dengan faktor resiko yang mengalami efek

$\mathrm{b}=$ subyek dengan faktor resiko yang tidak mengalami efek

$\mathrm{c}=$ subyek tanpa resiko yang mengalami efek

$\mathrm{d}=$ subyek tanpa faktor resiko yang tidak mengalami efek

Rumus Chi square:

$$
\mu^{2}=\frac{\varepsilon(\mathbf{O}-\mathbf{E})^{2}}{\mathbf{E}}
$$

Keterangan :

$\mu^{2}=$ Chi kuadrat hasil perhitungan

$\mathrm{O}=$ Frekuensi Observasi

$\mathrm{E}=$ frekuensi harapan (nilai yang diharapkan)

Interpretasi $=$ Ho ditolak jika $\mathrm{P}$ value $<$ 0,1 


\section{HASIL DAN PEMBAHASAN \\ 1. Karakteristik Responden}

\section{Tabel 1 Karateristik Responden Berdasarkan Umur}

\begin{tabular}{cccc}
\hline No & Umur & Frekuensi & Persentase \\
\hline 1 & $17-25$ & 28 & $28 \%$ \\
2 & $26-35$ & 49 & $49 \%$ \\
3 & $36-45$ & 23 & $23 \%$ \\
\hline \multicolumn{2}{c}{ Total } & 100 & $100 \%$ \\
\hline
\end{tabular}

Berdasakan tabel 1 dapat dilihat bahwa jumlah responden yang berusia 17-25 sebanyak 28 responden (28\%), 2635 sebanyak 49 responden (49\%), dan $36-45$ sebanyak 23 responden (23\%).

Tabel 2 Karakteristik Responden Berdasarkan Jenis Kelamin

\begin{tabular}{cccc}
\hline No & $\begin{array}{c}\text { Jenis } \\
\text { Kelamin }\end{array}$ & Frekuensi & Persentase \\
& Laki-laki & 50 & $50 \%$ \\
2 & Perempuan & 50 & $50 \%$ \\
\hline \multirow{2}{*}{ Total } & 100 & $100 \%$
\end{tabular}

Berdasakan tabel 2 dapat dilihat bahwa jumlah responden laki-laki sebanyak 50 responden (50.0\%), sedangkan jumlah responden perempuan sebanyak 50 responden $(50.0 \%)$.
Tabel 3 Karakteristik Responden Berdasarkan Pendidikan

\begin{tabular}{cccc}
\hline No & Pendidikan & Frekuensi & Persentase \\
\hline & TIDAK & & \\
1 & TAMAT & 2 & $\mathbf{2 \%}$ \\
& SD & & \\
2 & SD & 10 & $10 \%$ \\
3 & SMP & 14 & $14 \%$ \\
4 & SMA & 55 & $\mathbf{5 5 \%}$ \\
5 & S1 & 19 & $19 \%$ \\
\hline & Total & 100 & $100 \%$
\end{tabular}

Berdasarkan tabel 3 dapat dilihat bahwa jumlah responden menurut Pendidikan tidak tamat SD sebanyak 2 responden ( $2 \%$ ), lulus SD sebanyak 10 responden ( $10 \%$ ), lulus SMP sebanyak 14 responden ( $14 \%)$, lulus SMA sebanyak 55 responden ( $55 \%$ ), dan lulus S1 sebanyak 19 responden ( 19\% ).

\section{Tabel 4 Karakteristik Responden Berdasarkan Kelurahan}

\begin{tabular}{cccc}
\hline No & Kelurahan & Frekuensi & Persentase \\
\hline 1 & Telur & 62 & $68 \%$ \\
& Bayur & & \\
2 & Rinding & 38 & $38 \%$ \\
\hline \multicolumn{2}{c}{ Total } & 100 & $100 \%$
\end{tabular}

Berdasarkan tabel 4 dapat dilihat bahwa jumlah responden menurut Kelurahan Teluk Bayur sebanyak 62 responden ( $62 \%$ ) dan kelurahan Rinding sebanyak 38 responden ( $38 \%$ ). 
Tabel 5 Karakteristik Responden Berdasarkan Pekerjaan

\begin{tabular}{cccc}
\hline No & Pekerjaan & Frekuensi & Persentase \\
\hline 1 & Ibu Rumah & 44 & $\mathbf{4 4 \%}$ \\
& Tangga & & \\
2 & PNS & 5 & $\mathbf{5 \%}$ \\
3 & Wiraswasta & 15 & $15 \%$ \\
4 & Karyawan & 26 & $26 \%$ \\
& Swasta & & \\
5 & Lainnya & 10 & $10 \%$ \\
\hline & Total & 100 & $100 \%$ \\
\hline
\end{tabular}

Berdasarkan tabel 5 dapat dilihat bahwa jumlah responden menurut Pekerjaan yang paling tinggi adalah ibu rumah tangga sebanyak 44 responden ( $44 \%$ ), dan yang paling rendah. PNS sebanyak 5 responden ( $5 \%$ ), wiraswasta sebanyak 15 responden ( $15 \%)$, karyawan swasta sebanyak 26 responden ( $26 \%$ ), dan lainnya sebanyak 10 responden ( $10 \%)$.

\section{Tabel 6 Karakteristik Responden} Berdasarkan Pendapatan

\begin{tabular}{|c|c|c|c|}
\hline No & Pendapatan & Frekuensi & Persentase \\
\hline \multirow[t]{2}{*}{1} & Sangat Tinggi Rp & 9 & $9 \%$ \\
\hline & 3.500 .00 & & \\
\hline \multirow[t]{3}{*}{2} & Tinggi Rp & 39 & $39 \%$ \\
\hline & 2.500.000 hingga & & \\
\hline & Rp 3.500.000 & & \\
\hline \multirow[t]{3}{*}{3} & Sedang Rp & 40 & $40 \%$ \\
\hline & 1.500.000 hingga & & \\
\hline & $\mathrm{Rp} 2.500 .00$ & & \\
\hline \multirow[t]{3}{*}{4} & Rendah Rp & 12 & $12 \%$ \\
\hline & 1.500 .00 & & \\
\hline & Total & 100 & $100 \%$ \\
\hline
\end{tabular}

Berdasarkan tabel 6 dapat dilihat bahwa jumlah responden menurut Pendapatan sangat tinggi Rp 3.500.00 sebanyak 9 responden ( $9 \%$ ), tinggi $\mathrm{Rp}$ 2.500.000 hingga Rp 3.500 .000 sebanyak 39 responden ( $39 \%$ ), sedang Rp 1.500.000 hingga Rp 2.500 .000 sebanyak 40 responden ( $40 \%$ ),dan rendah $\mathrm{Rp} \quad 1.500 .000$ sebanyak 12 responden (12\%).

Tabel 7 Karakteristik Responden Berdasarkan Anggota Keluarga yang pernah menderita DBD

No Anggota Frekuensi Presentase Keluarga

\begin{tabular}{cccc}
\hline 1 & Ya & 20 & $20 \%$ \\
2 & Tidak & 80 & $80 \%$ \\
\hline & Total & 100 & $100 \%$
\end{tabular}

Berdasarkan tabel 7 dapat dilihat bahwa jumlah responden menurut anggota keluarga yang pernah terkena DBD menjawab "Ya" sebanyak 20 responden ( $20 \%$ ) dan anggota keluarga “tidak" sebanyak 80 responden ( $80 \%$ ).

\section{Analisis Univariat}

Tabel 8 Karakteristik Responden Berdasarkan Pengetahuan

\begin{tabular}{cccc}
\hline No & Pengetahuan & $\begin{array}{c}\text { Frekuen } \\
\text { si }\end{array}$ & Persentase \\
\hline 1 & Baik & 58 & $\mathbf{5 8 \%}$ \\
2 & cukup & 39 & $39 \%$ \\
3 & Kurang & 3 & $\mathbf{3 \%}$ \\
\hline & Total & 100 & $100 \%$ \\
\hline
\end{tabular}


Berdasarkan tabel 8 dapat dilihat bahwa jumlah responden yang berpengetahuan baik sebanyak 58\% sementara yang terendah ialah berpengetahuan kurang sebanyak $3 \%$.

Tabel 9 Karakteristik Responden Berdasarkan Sikap

\begin{tabular}{|c|c|c|c|}
\hline No & Sikap & Frekuensi & Persentase \\
\hline 1 & Negatif & 10 & $10 \%$ \\
\hline 2 & Positif & 63 & $63 \%$ \\
\hline 3 & $\begin{array}{l}\text { Sangat } \\
\text { positif }\end{array}$ & 27 & $27 \%$ \\
\hline & tal & 100 & $100 \%$ \\
\hline
\end{tabular}

Berdasarkan tabel 9 dapat dilihat bahwa jumlah responden yang bersikap positif sebanyak $63 \%$ sementara yang terendah ialah bersikap negatif sebanyak $10 \%$.

\section{Tabel 10 Karakteristik Responden Berdasarkan Tindakan}

\begin{tabular}{llll}
\hline No & Tindakan & Frekuensi & Persentase \\
\hline 1 & Tidak & 69 & $69 \%$ \\
& Melakukan & & \\
& $3 \mathrm{M}$ & & \\
2 & Melakukan & 31 & $31 \%$ \\
& $3 \mathrm{M}$ & & \\
\hline & Total & 100 & $100 \%$
\end{tabular}

Berdasarkan tabel 10 dapat dilihat bahwa jumlah responden yang melakukan 3 M sebanyak $31 \%$ sementara yang tidak melakukan $3 \mathrm{M}$ sebanyak $69 \%$.
Tabel 11 Karakteristik Responden Berdasarkan Tindakan

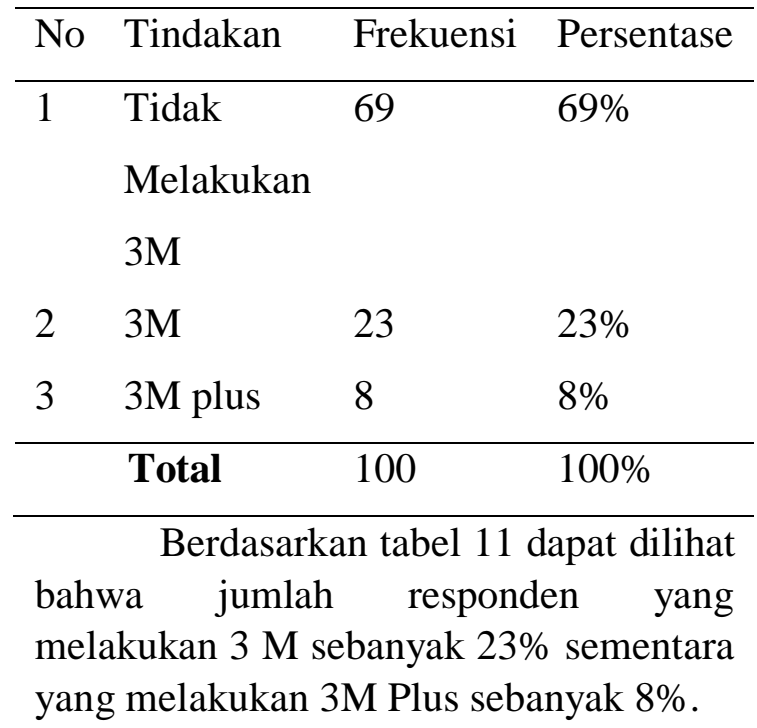

\section{Analisis Bivariat}

\section{a. Hubungan Antara pengetahuan dan pencegahan DBD}

Tabel 1 hubungan pengetahuan dan pencegahan DBD

\begin{tabular}{ccccc}
\hline \multirow{2}{*}{ DBD } & \multicolumn{4}{c}{ kategori pengetahuan } \\
& Baik & Cukup & kurang & Total \\
\hline Tidak & 44 & 35 & 1 & 80 \\
Ya & 14 & 4 & 2 & 20 \\
\hline Total & 58 & 39 & 3 & 100 \\
\hline
\end{tabular}

Dari uji chi square menunjukan bahwa ada hubungan yang bermakna pada variabel pengetahuan dan kejadian DBD pada taraf kepercayaan $90 \%$ karena nilai $P$ vaule $=0.030$ lebih kecil dari alpha $=0.1$. Jadi ada hubungan antara pengetahuan pengunjung Pusat kesehatan masyarakat dengan pencegahan Demam Berdarah Dengue .

Hubungan pengetahuan pengunjung Pusat kesehatan masyarakat terhadap pencegahan dianalisis dengan 
menggunakan tabel silang dan dilakukan uji statistik. Dari hasil perhitungan $C h i$ square diperoleh nilai $P$ - value adalah 0.030 (lebih kecil dari alpha $=0.1$ ) berarti ada Hubungan pengetahuan pengunjung Pusat kesehatan masyarakat terhadap pencegahan Demam Berdarah Dengue .

Dari penelitian ini yang mengalami DBD dengan pengetahuan yang baik berjumlah 14 orang yang di karenakan pengunjung mendapatkan pengalaman setelah terkena DBD sehingga pengetahuan mereka tentang tindak pencegahan DBD naik. Faktor lingkungan juga menjadi penentu karna pengetahuan yang baik belum cukup hal ini bisa di lihat dari angka yang terkena DBD dengan pengetahuan baik cukup tinggi. Hal ini sejalan dengan penelitian tentang Hubungan Faktor Lingkungan dan Perilaku Masyarakat dengan Keberadaan Vektor Demam Berdarah Dengue (DBD) di Wilayah Kerja Puskesmas I Denpasar Selatan tahun 2013 yang menyatakan Dengan mengetahui pengetahuan yang baik tidak berarti dapat memprediksi tindakan yang dilakukan, ketika pengetahuan seseorang baik/positif tindakan yang diambilnya negatif begitu sebaliknya(Gede Yusada, 2013).

\section{b. Hubungan antara sikap dan pencegahan DBD}

\section{Tabel 2 hubungan sikap dan} pencegahan DBD

\begin{tabular}{ccccc}
\hline & \multicolumn{4}{c}{ kategori sikap } \\
DBD & $\begin{array}{c}\text { Sangat } \\
\text { positif }\end{array}$ & Positif & Negatif & Total \\
& & & \\
\hline Tidak & 18 & 52 & 10 & 80 \\
Ya & 9 & 11 & 0 & 20 \\
\hline Total & 10 & 63 & 27 & 100 \\
\hline
\end{tabular}

Dari uji chi square menunjukan bahwa ada hubungan yang bermakna pada variabel sikap dan kejadian DBD pada taraf kepercayaan $90 \%$ karena nilai $P$ vaule $=0.056$ lebih kecil dari alpha $=$ 0.1 . Jadi ada hubungan antara sikap pengunjung Pusat kesehatan masyarakat dengan pencegahan Demam Berdarah Dengue.

Hubungan sikap pengunjung Pusat kesehatan masyarakat terhadap pencegahan dianalisis dengan menggunakan tabel silang dan dilakukan uji statistik. Dari hasil perhitungan $C h i$ square diperoleh nilai $\mathrm{P}$ - value adalah 0.56 (lebih kecil dari alpha $=0.1$ ) berarti ada Hubungan sikap pengunjung Pusat kesehatan masyarakat terhadap pencegahan Demam Berdarah Dengue .

Dari penelitian ini yang mengalami DBD dengan sikap sangat positif berjumlah 9 orang. Sikap sangat positif ini muncul di karenakan pemahaman masyarakat yang dahulu terkena DBD akibat dari sikap mereka yang kurang mundukung terhadap program 3M sehingga setelah terkena DBD mereka sadar bahwa perlunya sikap mendukung program $3 \mathrm{M}$ agar masyarakat tidak terkena DBD. 
Dalam penelitian ini sejalan dengan penelitian hubungan yang bermakna antara sikap dengan tindakan pencegahan DBD pada masyarakat di wilayah kerja Puskesmas Kolongan Minahasa Utara. Sikap responden merupakan respon yang sudah bersifat terbuka dan telah tampak dalam kehidupan nyata sehingga tercermin dalam tindakan pencegahan yang mereka lakukan secara lebih baik sesuai dengan sikap positif mereka terhadap upaya pencegahan itu sendiri (Montung, 2012).

Hasil penelitian ini sesuai dengan teori yang mengatakan sikap merupakan reaksi atau respons tertutup seseorang terhadap stimulus atau objek tertentu, yang sudah melibatkan faktor pendapat dan emosi yang bersangkutan (senangtidak senang, setujutidak setuju, baiktidak baik, dan sebagainya). (Notoatmodjo, 2010).

\section{c. Hubungan antara tindakan dan pencegahan DBD}

\section{Tabel 3 hubungan praktik dan} pencegahan DBD

\begin{tabular}{cccc}
\hline & \multicolumn{3}{c}{ kategori tindakan } \\
DBD & Melakukan & Tidak & Total \\
& $3 \mathrm{M}$ & melakukan & \\
& & $3 \mathrm{M}$ & \\
\hline Tidak & 22 & 58 & 80 \\
Ya & 9 & 11 & 20 \\
\hline Total & 69 & 31 & 100 \\
\hline
\end{tabular}

Dari uji chi square menunjukan bahwa tidak ada hubungan yang bermakna pada variabel praktik dan kejadian DBD pada taraf kepercayaan $90 \%$ karena nilai $P$ vaule $=0.130$ lebih besar dari alpha $=$ 0.1 . jadi tidak ada hubungan antara tindakan pengunjung Pusat kesehatan masyarakat dengan pencegahan Demam Berdarah Dengue .

Dari uji chi square menunjukan bahwa tidak ada hubungan yang bermakna pada variabel praktik dan kejadian DBD pada taraf kepercayaan 90 $\%$ karena nilai $P$ vaule $=0.130$ lebih besar dari alpha $=0.1$. jadi tidak ada hubungan antara tindakan pengunjung Pusat kesehatan masyarakat dengan pencegahan Demam Berdarah Dengue .

Dalam penelitian ini yang mengalami DBD dengan responden yang tidak melakukan 3M sebanyak 11 orang hal ini di karenakan adanya faktor lain yang menjadi penentu terjadi DBD yaitu lingkungan yang banyak tergenang air dan banyak sampah kaleng yang menjadi sarang tempat berkembang biak nyamuk DBD, hal ini tidak sesuai dengan teori yang mengatakan tindakan merupakan kelanjutan dari pengetahuan dan sikap yang dimanifestasikan sebagai suatu tindakan seseorang dari stimulus tertentu, termasuk tindakan pemberantasan sarang nyamuk Demam Berdarah Dengue. untuk terwujudnya sikap menjadi tindakan nyata diperlukan suatu faktor pendukung atau kondisi yang memungkinkan diantaranya adalah pengetahuan yang baik dan sikap yang positif sehingga kegiatan Pemberantasan Sarang Nyamuk Demam Berdarah Dengue yang dilakukan akan terlaksana dengan baik. (Deddy,2013)

Hal ini tidak sejalan dengan hasil penelitian hubungan keberadaaan jentik aedes aegypti dan pelaksaan 3M PLUS dengan kejadian penyakit DBD di lingkungan XVIII di Kelurahan Binjai Kota Medan Tahun 2012 tindakan pelaksanaan 3M Plus oleh responden memiliki hubungan dengan kejadian penyakit Demam Berdarah Dengue (DBD) di Lingkungan XVIII Kelurahan Binjai. hal ini menunjukkan bahwa 
meskipun sebahagian besar masyarakat di Lingkungan XVIII sudah melakukan tindakan pencegahan berupa pelaksanaan 3M Plus, akan tetapi kejadian DBD di lingkungan tersebut masih tetap terjadi. (Sulina Parida S,2012)

\section{SIMPULAN}

1. Ada hubungan antara pengetahuan pengunjung Puskesmas dengan pencegahan DBD.

2. Ada hubungan antara sikap pengunjung Puskesmas dengan pencegahan DBD.

3. Tidak ada hubungan antara tindakan pengunjung Puskesmas dengan pencegahan DBD.

\section{DAFTAR PUSTAKA \\ Buku/Literatur:}

Arikunto, Suharsimi. 2010. Prosedur Penelitian. Jakarta: Rineka Cipta.

CNN INDOENESIA,2016. Indonesia Peringkat Dua Negara Endemis Demam Berdarah. https://www.cnnindonesia.com/gay a-hidup/20160616170332-255138672/indonesia-peringkat-duanegara-endemis-demam-berdarah. Di akses pada tanggal 2 Mei 2018

Deddy , Hasim maulana,2013. faktorfaktor yang berhubungan dengan tindakan pemberantasan sarang nyamuk DBD di kabupaten Mesuji. Jurnal Kesehatan Poltekes Kesehatan Kementrian Kesehatan Tanjung Karang. Vol. 4 No.2 Tahun 2013.

Depkes, 2016. Profil Kesehatan Kesehatan Kalimantan timur 2016. Berau

Dinas Kesehatan Berau, 2017, Profil Kesehatan Kabupaten Berau 2017, Berau.

Gede yusada,,2013. Hubungan Faktor Lingkungan dan Perilaku Masyarakat dengan Keberadaan
Vektor Demam Berdarah Dengue (DBD) di Wilayah Kerja Puskesmas I Denpasar Selatan. ECOTROPHIC : Jurnal Ilmu Lingkungan (Journal of Environmental Science), [S.1.], vol. 3, No. 1, Nov. 2012. ISSN 25033395

info Datin, 2016. 22 April-Hari Demam Berdarah Dengue Situasi Dbd. Di Indonesia Pusat Data Dan Informasi Kementrian Kesehatan Ri.

Kemenkes RI,2016. Kendalikan DBD Dengan PSN 3M Plus http://www.depkes.go.id/article/vie w/16020900002/kendalikan-dbd dengan-psn-3m-plus.html di akses tanggal 3 Mei 2018

Kemenkes ri,2017. Demam berdarah dengue.

Montung, D. 2012. Hubungan Antara Karakteristik Individu, Pengetahuan, Sikap Dengan Tindakan Masyarakat Dalam Pencegahan Demam Berdarah Dengue Di Wilayah Kerja Puskesmas Kolongan Minahasa Utara. (Tesis), Manado: Universitas Sam Ratulangi.

Notoatmodjo S,2010. Ilmu Perilaku Kesehatan. Jakarta: Rineka Cipta;

Notoatmodjo S.2007. Kesehatan Masyarakat Ilmu dan Seni. Jakarta: Rineka Cipta

Puskesmas Teluk Bayur. 2015. Profil Puskesmas Teluk Bayur tahun 2015. Berau

Puskesmas Teluk Bayur. 2016. Profil Puskesmas Teluk Bayur tahun 2016. Berau

Puskesmas Teluk Bayur. 2017. Profil Puskesmas Teluk Bayur tahun 2017. Berau

Sulina Parida S,2012. hubungan keberadaaan jentik aedes aegypti 
dan pelaksaan 3M PLUS dengan kejadian penyakit DBD di lingkungan XVIII di kelurahan binjai kota medan. Skripsi.

WHO, 2018. Dangue And Severe Dengue. From World Health Organization. 